\title{
Nilai Pendidikan Islam dalam Pengajian Lapanan
}

\author{
Bahrun Ali Murtopo \\ Institut Agama Islam Nahdlatul Ulama (IAINU) Kebumen \\ bahrunalimurtopo@gmail.com
}

\begin{abstract}
Astrak
Majlis Ta'lim dan Nilai-nilai Keagamaa. Munculya majlis ta'lim dewasa ini merupakan fenomena menarik. Majlis ta'lim lahir bersamaan dengan kompleksitas persoalan yang dihadapi di masyarakat, seperti pencurian, narkoba, pergaulan bebas dan lain sebagainya. Oleh karena itu, bermula dari kesadaran masyarakat untuk membendung persoalan tersebut melalui pemahaman dan peningkatan nilai-nilai agama mutlak dilakukan. Majlis ta'lim tidak sekedar sebagai aktivitas keagamaan yang lebih mengutamakan aspek ritualistik, lebih jauh majlis ta'lim membenahi diri sebagai proses pendidikan, yang mengajarkan dan berperan menanamkan nilai-nilai keagamaan pada masyarakat sebagai tambahan sepiritual relijius. Aqidah tentang keimanan yang mencakup rukun Iman yang lima, akhlak atau perilaku seperti mengucapkan salam ketika bertamu dan menghormati orang. dalam menanamkan nilai-nilai keagamaan bagi masyarakat adalah berperan sebagai kreator (yang pertama memulai atau mengawali), fasilitator (yang menyediakan), dan edukator (pendidikan). membuat kegiatan pengajian lapanan pada masyarakat dan remaja agar remaja di desa lebih aktif pada kegiatan keagamaan, sosial dan budaya yang baik untuk menambah atau memaksimalkan Peranan masyarakat dalam kehidupan sosila masyarakat.
\end{abstract}

Kata Kunci: Nilai Pendidikan Islam, Pengajian Lapanan

\section{Pendahuluan}

Pengajian lapanan merupakan salah satu ibadah tambahan sebagai mendekatkan diri kepada sang pencipta-Nya dengan cara melakukan kegiatan yang sudah tercantum pengajian lapangan yang sudah terpimpin oleh seorang kyai.

Pengajian lapanan adalah ibadah tambahan yang merupakan amaliah yang dilakukan seorang setelah melakukan kewajiban ibadah wajib, ibadah yang di maksud dalam pengajian lapanan disini adalah ibadah yang tidak mengganggu kewajiban sebagai hamba Alloh SWT yaitu melaksanakan perintah dan menjauhi larangannya. Pengajian lapanan di sajikan bagi orang-orang yang ingin berkumpul dan mau mencari ilmu.

Pengajian lapanan merupakan tradisi islami. Tradisi ini bisa hilang apabila tatanan kehidupan pada tingkat makro sudah termasuki dari dampak globlalisasi, salah satu dari unguri-uri tradisi ini adalah mengaktualisasikan nilai -nilai islami dalam kehidupan sosial.

Demikian kehidupan sosial dewasa ini terjadi perubahan sangat drastis berbagai sektor, bahwa perubahan tersebut meliputi ekonomi sosial budaya sampai pada kesadaran untuk beragaman dan juga perubahan pada moral. Pada saat sekarang ini banyak terjadi fenomena perubahan sosil dalam masyarakat 
khususnya dalam perilaku yang mengalami penurunan moral yang mengakibatkan menurunya nilai etika dan tata krama dalam masyarakat.

Hal ini disebabkan pula karena masih rendahnya tingkat pendidikan, masyarakat kemampuan selektif dan adaptasi dengan hilangnya nilai tradisi sebagai pengikat kehidupan bersama mulai melonggar, sehingga terjadi banyak penyimpangan sosial. Salah satu dampaknya ialah meningkatnya kriminalitas, bahkan ada yang mengatakan bahwa masyarakat modern telah menderita penyakit kleptokrasi.

Bentuk-bentuk kleptokrasi ini misalnya terlihat di dalam semakin meningkat gejala-gejala korupsi ${ }^{1}$.

Pemahaman di atas tidak sesuai dengan pengajian lapanan sebagai salah satu jalan untuk mendekatkan diri kepada Allah dengan sunguh-sunguh dan iklas dalam beribadah serta tidak berperasangka buruk akan apa yang mereka alami jika tidak sesuai yang diinginkan. Berbagai ujian dan cobaan haruslah dianggap sebagi cambuk untuk memperbaiki segala kekurangan yang ada didalam dirinya manusia serta harus bertakwal berserah diri setelah melakukan usah dan doa. Salah satu dari usaha tersebut adalah dengan adanya pengajian lapanan yang berusaha untuk menampung jama'ah pengajian yang ada, dengan tujuan untuk menjadikan jam'ah pengajian dalam hal ini sebagai murid lebih arif dan bijaksana dalam menjalankan kehidupan sebagi hamba Allah.

\section{Pembahasan}

Berikut ini akan dibahas secara singkat dan padat tiga hal Nilai-nilai, Pendidikan Islam, Pengajian Lapanan, Tradisi ini bisa hilang apabila tatanan kehidupan pada tingkat makro sudah termasuki dari dampak globlalisasi, salah satu dari unguri-uri tradisi ini adalah mengaktualisasikan nilai -nilai islami dalam kehidupan sosial.

\section{Pengertian Pengajian Lapanan}

Pengajian lapanan dalam bahasa Arab disebut At-ta'llimu asal kata Ta'allamu yaitu yata'allmu ta'liiman yang artinya belajar, pengertian dari makna pengajian atau ta'liim menpunyai nilai ibadah tersendiri, hadir dalam belajar ilmu agama bersama seorang yang berilmu².

Ibadah wajib, ibadah yang dimaksudkan dalam pengajian lapanan disini adalah ibadah yang tidak mengganggu kewajiban sebagai hamba Allah SWT yaitu melaksanakan perintah-Nya dan menjauhi larangan-Nya, pengajian lapanan di sajikan bagi orang-orang yang ingin berkumpul dan mau mencari ilmu.

1 H.A.R Tilaar, Perubahan Sosial Dan Pendidikan Pengantar Pedogogik Transformatif Untuk Indonesia, (Jakarta: PT Gransindo. 2002), h 65

2Tutty Alawiyah, Strategi Dakwah di Lingkungan Majelis Taklim, cet. I, (Bandung: Mizan, 1997), , h. 78

RI'AYAH, Vol. 02, No. 01 Januari-Juni 2017 


\section{Dasar Pengajian Lapanan}

Dasar pengajian lapanan adalah kesepakatan berdasarkan musawarah dalam rangka untuk mencari ilmu secara bersama atau berjamaah., dasar itu disesuaikan dengan hadis.

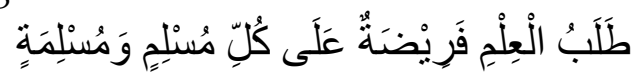

Artinya : "Mencari ilmu itu adalah wajib bagi setiap muslim laki-laki maupun muslim perempuan". (HR. Ibnu Abdil Barr)

\section{Tujuan Pengajian Lapanan}

Dalam pengajian terdapat manfaat yang begitu besar positifnya, di dalam pengajian-pengajian manfaat yang dapat di ambil menambah dari salah satu orang yang bisa berbuat negatif dengan memanfaatkanya menjadi positif. Hal seperti ini pada masyarakat muslim pada umumnya dapat memanfaatkan pengajian untuk merubah diri atau memperbaiki diri dari perbuatan yang keji dan mungkar ${ }^{3}$

4. Pengajian Lapanaan Sebagai Pengembangan Masyarakat Konsep Dakwah

Pengajian lapanan yang dilaksanakan secara rutin merupakan media pendidikan islam dan da'wah kearah traformasi sosial keagamaan sehingga terbangunlah kehidupan individu dan masyrakat Islami, dalam kontek ini da'wah merupakan upaya untuk melakukan perubahan kearah perbaikan umat serta memaksimalkan nilai-nilai Islami.

Pengkajian lapanan sebagai kebutuhan dasar manusia mengakutualisasi spiritual. Pengajian lapanan di dalam tatanan sosial sebagai konsepsi akan pembangunan manusia seutuhnya. Pengembangan masyarakat selalu dirangkai dengan adanya perpedaan masyarakat dalam mendorong tumbuhnya masyarakat sikap dan perilaku masyarakat yang kondusif untuk kemajuan serta meningkatkan serta meningkatkan kualitas partisipatif masyarakat, menghidari dan menjadi kontributor program da'wah.

David Ckroren memberi makna terhadap pembangunan sebagai upaya memberikan kontribusi pada aktualisasi pontensi tertinggi dalam kehidupan manusia. Menurut pembangunan selayaknya ditunjukkan untuk mencapai sebuah standar kehidupan yang menjamin kebutuahn dasar manusia4.

Hal ini merupakan tahapan yang ensesial dan fundamental menuju tercapainya tujuan kesejahteraan manusia. Kebutuhan dasar tidak dilihat dalam batasan-batasan minimum manusia, yaitu kebutuhan akan makan, 1997, h. 78

3 Tutty Alawiyah, Strategi Dakwah di Lingkungan Majelis Taklim, ), cet. I, (Bandung: Mizan,

${ }^{4}$ Moh, Ali aziz, Rr. Surhartini, A. Halim, Dakwah Pemperdayaan Masyarakat Pradikma aksi Metodologis, cet pertama. (Yogyakarta: LKIS, 2005), h.5

RI'AYAH, Vol. 02, No. 01 Januari-Juni 2017 
tempat tinggal dan pakaian, tetapi juga sebagai kebutuhan rasa aman, kasih sayang, mendapatkan kehormatan dan kesempatan untuk berkerja secara fair. Serta tentu saja aktualisasai spiritual. Konsepsi akan pembangunan manusia seutuhnya (Insan Kamil) dalam Prekvetif Agama agaknya cukup relevan dalam kontek ini.

Berapa asumsi yang di gunakan dalam rangka mewujudkan semangat akan di kemukan sebagai berikut. Pertama, pada intinya upayaupaya pengembangan masyarakat dapat di lihat sebagai peletakan sebuah tatanan sosial di mana manusia secara adil dan terbuka dapa melakukan usahanya sebagai perwujudan atas kemampuan dan pontensi yang dapat di milikinya sehingga kebutuhan (material dan sepirittual) dapt di penuhi.

Kedua, pengembangan masyarakat mesti dilihat sebagai sebuah proses pembelajaran pada masyarakat agar mereka dapat secara mandiri melalkukan upaya-upaya perbaikan kualitas hidupanya. Ketiga pembangunan masyarkat, oleh karena itu, mungkin dilaksanakan tampa terlibat penuh oleh masyarakt itu sendiri. Parsitisipasi bukan seuatu kegiatan, melainkan dipahami sbagi kontribusi mereka dalam setiap yang dilalui oleh satu program kerja pengembangan masyarakat, terutama dalam tahapan perumusan kebutuhan yang mesti dipenuhi.

Keempat pemnembanganmasyarakat selalu diterangai adamya pemberdayaan. Tidak mungkin tuntunan akan keterlibatan masyrakat dalam suatu program pembangunan, karena itu, mesti ada mekanisme dan sistem untuk menbaerdayakan. Memang, sering kali people empowerment di awali dengan mengubah cara padang menerima menjadi aktif partisipatif5.

Disamping konsep dasar di atas,ada beberapa prinsip yang lain harus dipenuhi dalam dakwah pengembangan masyarakat :

a. Prinsip kebutuhan

Artinya program dakwah harus di dasarkan atas dan untuk memenuhi kebutuhan masyarakat yang bersifat fisik matrial, tetapi juga non matrial.

b. Prinsip Partisipasi

Prinsip dakwah ini menekankan pada keterlibatan masyarakat secara aktif dalam proses dakwah, mulai dari perencanaan, pengorganisasian, penggerakan, penilaian, dan pengembangan.

Prinsip ini antara lain bertujuan untuk : Pertama. Mendorong tumbuhnya sikap dan perilaku masyarakat yang kondusif untuk kemajuan. Kedua. Meningkatkan kualitas partisipasif masyarakat dan sekedar mendukung, menghadiri dan menjadi kontributor program

5 Moh, Ali aziz, Rr. Surhartini, A. Halim, Dakwah Pemperdayaan Masyarakat Pradikma aksi Metodologis, cet pertama. (Yogyakarta: Lkis, 2005), h. 6-7.

RI'AYAH, Vol. 02, No. 01 Januari-Juni 2017 
dakwah. Ketiga. Menyegarkan dan meningkatkan efektivitas fungsi dan peran pemimpin lokal.

c. Prinsip Kerterpaduan

Mencerminkan adanya upaya untuk memadukan seluruh potensidan sumber daya alam yang dimiliki oleh masyarakat. Dalam konteks inilah dakwah oleh pengembangan masyarakat itu bukan monopoli sekelompok orang dan ahli, atau organisasi, melinkan lebih luas dari pada itu, yaitu siapapun yang mempunyai komitmen community development yang berbijak pada universalitas nilai-nilai islam adalah bagian dari pengembangan masyarakat.

d. Prinsip Berkelanjutan

Prinsip ini menekankan bahwa dakwah itu harus sustainable. Artinya, dakwah harus berkelanjutan yang tidak dibatasi oleh waktu, pada saatnya mereka adalah anmggota masyarakat itu sendiri. Prinsip yang berkelanjutan inilah di dalam Al-Qur'an disebut dengan istiqomah yang mampu menciptakn kesakteraan dan kesamaan lahir batin.

e. Prinsip Keserasian

Mengandung makna bahwa program dakwah pembangunan masyrakat harus mempertimbangkan keserasian kebutuhan jasmaniah dan rohaniah masyrakat. 6

Sebagai mana telah dijelaskan dalam surat An-Nahl ayat 125.

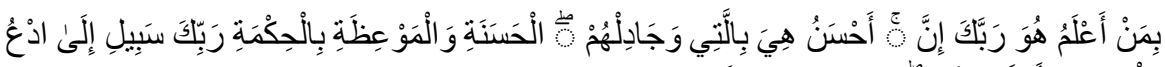

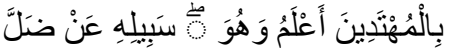

"Serulah (manusia) kepada jalan tuhanmu dengan himah dan pelajaran yang baik dan bantahlah mereka dengan cara yang baik. Sesungguhnya Tuhanmu dialah yang lebih mengetahui tentang siapa yang tersesat dari jalan-Nya dan Dialah yang lebih mengetahui orang-orang yang mendapat petunjuk". ${ }^{\prime}$

\section{Aplikasi Psikologi Dakwah Untuk Kebutuhan Dasar Manusia}

Menurut kamus ilmiah populer edisi lengkap psikologi adalah ilmu jiwa/gejala kejiwaan. ${ }^{8}$ Jiwa yang dimaksud adalah daya hidup rohaniah yang bersifat abstrak, ynag menjadi penggerak dan pengatur bagi perbuatan pribadi dari hewan dan manusia, perbuatan pribadi ialah sebagaian proses hasil belajar yang dimungkinkan oleh keadaan jasmani, rohaniah, sosial dan lingkungan. ${ }^{9}$

${ }^{6}$ Ibid, hal. 16-18

7 Abdullah bin Abdul Aziz Sa'ud, Al-Qur'an dan Terjemahannya, (Jakarta: Yayasan Penyelenggaraan Penerjemahan/Penafsiran Al-Qur'an, 1971), h. 421

8 Tim Prima Pena, Op. Cit., h. 392.

${ }^{9}$ H. Ahmad Fauzi, Psikologi Umum, cet kedua, (Bandung: CV Pustaka Setia, 1999), h. 9.

RI'AYAH, Vol. 02, No. 01 Januari-Juni 2017 
Setiap manusia mempunyai kebutuhan yang harus dipenuhinya, untuk memahami masalah dan segala problem yang menyertainya, kita harus memahami apa saja kebutuhan manusia. Dalam hal ini banyak banyak para pakar psikologi mengajukkan berbagai pemikirannya, suatu teori yang cukup populer dikalangan para pakar psikologi dan ilmuan lainnya adalah teori hirarki kebutuhan yang diutarakan oleh Abraham B. Maslow.

Menurut Abraham B. Maslow kebutuhan manusia pada dasarnya bertingkat-tingkat, mulai dari tingkat yang paling bawah sampai ketingkat yang paling tinggi. Kebutuhan pada tingkatan yang paling tinggi tidak mungkin timbul sebelum kebutuhan dasar terpenuhi. Secara sedikit lebih terperinci, tingkatan kebutuhan manusia antara lain yaitu:

a. Kebutuhan Fisiologi

Kebutuhan inilah adalah kebutuhan dasar yang harus terpenuhi oleh setiap manusia untuk hidup, makan, minum, dan istirahat dalah contohcontoh dari kebutuhan dasar ini. ${ }^{10}$

b. Kebutuhan Rasa Aman

Setelah manusia dapat memenuhi kebutuhan akan makan, minum, dan istirahat, selanjutnya berkembang keinginan untuk memperoleh rasa aman.

c. Kebutuhan Akan Rasa Kasih Sayang

Perasan akan memiliki dan dimiliki oleh orang lain untuk kelompok masyarakat adalah suatu yang dibutuhkan oleh setiap manusia.

d. Kebutuhan Akan Harga Diri

Bila Kebutuhan pada tingkat sudah terpenuhi, maka akan muncul kebutuhan akan harga diri, agar dirinya dihargai oleh manusia sebagai warga negara, maka seseorang akan berbuat sesuatu yang berguna. Pada tahapan ini orang juga menginginkan buah pikirannya dihargai. ${ }^{11}$

e. Kebutuhan Akan Aktualisasi

Kebutuhan pada tingkat ini adalah kebutuhan yang paling tinggi, pada tingkatan ini manusia akan berbuat sesuatu semata karena dorongan dari dalam, dia tidak lagi mengharapkan penghargaan orang. Sesuatu yang ingin didalam kebutuhan tingkat ini adalah keindahan, kesempurnaan, keadilan dan kebermaknaan. ${ }^{12}$

10 Djamaludin Anclok dan Fuad Nashori Suroso, Psikologi Islam, cet pertama, (Yogyakarta: Pustaka Pelajar, 1940), h. 48

11 Djamaludin Anclok dan Fuad Nashori Suroso, Psikologi Islam, cet pertama, (Yogyakarta: Pustaka Pelajar, 1994), h. 48-.49

12 Santoso Sembiring, Himpunan Perundang Undangan Republik Indonesia, cet pertama, (Bandung : CV Nuansa Aulia, 2006), h. 97.

RI'AYAH, Vol. 02, No. 01 Januari-Juni 2017 


\section{Pendidkian Agama Islam}

Pendidkan mempunyai ruang lingkup yang cukup luas, yang selalu mengandung pikiran para ahli dan pencinta pembaharuan. Para cendekiawan di bidang pendidikan masing-masing memberi pandangan tentang maslah yang berhubungan dengan pendidikan. Sekalipun mereka berlainan pendpat dalam memberi batasan tentang pendidikan, akan tetapi ada kesepakatan diantara mereka bahwa pendidikan itu dilaksanakan utuk mengembangkan potensi yang ada pada dirinya, demi kesempurnaan pribadinya.

a. Pendidikan adalah usaha sadar dan terencana untuk mewujudkan suasan belajar dan proses pembelajaran agar secara aktif mengembangkan potensi dirinya untuk memiki kekuatan spiritual keagamaan, penegndalian diri, kepribadian, kecerdasan, akhlak mulia serta ketrampilan yang diperlukan dirinya, masyarakat dan negara. ${ }^{13}$

b. Menurut Ki Hajar Dewantara " Pendidkan adalah usaha yang dilakukan dengan penuh keinsyafan yang ditunjukan untuk keselamatan dan kebahagiaan umat".

c. Hasan Langgulung mendefinisikan pendidkan islam adalah proses penyiapan generasi muda untuk mengisi peranan, memindahkan pengetahuan dan nilai-nilai islam yang diselaraskan dengan fungsi manusia untuk di dunia adan memetik hasilnya di akhirat.

Pendidkan agama islam diartikan sebagai uasaha mengubah tingkah laku individu dalam kehidupan pribadinya atau kehidupan masyarakatnyanya dan kehidupan alam sekitarnya melalui proses kependidikan. Pendidkan Islam adalah bimbingan jasmani dan rohani berdasarkan hukum-hukum islam menuju kepada pribadian utama menurut ukuran islam.

Pemahaman diatas kita tarik kesimpulan bahwa pendidikan agama islam adalah bimbingan dan usaha yang diberikan kepada seseorang dalam pertumbuhan jasmani dan rohani agar tertanam nilai-nilai ajaran agama islam untuk menuju pada tingkat membentuk kepribadian yang utama, yaitu kepribadian muslim yang mencapai kehidupan dunia dan akhirat.

Dengan demikian bahwa pedidikan agama islam berusaha untuk merealisasikan misi agama islam dalam setiap pribadi manusia yaitu menjadikan manusia sejahtera dan bahagia dalam cita-cita islam yang mencerminkan nilai-nilai normatif dari Tuhan yang bersifat abadi dan absolute, nilai-nilai islam itulah yang harusnya ditumbuh kembangkan 
berkepribadian islam akan tetapi merasa berada pada lingkaran hubungan vertikal dengan tuhanya dan hubungan horisontal dengan manusia.

\section{Tujuan dan Dasar Pendidikan Islam}

Tujuan pendidikan islam adalah manusia yang baik. Marimba berpendapat tujuan pendidikan islam adalah terbentuknya nerkepribadian muslim. Al Abrasyi menghendaki tujuan akhir akhir dari pendidikan islam adalah manusia yang berakhlak mulia. Munir Mursyi menyatakan bahwa tujuan akhir pendidikan menurut islam adalah manusia yang sempurna. ${ }^{14}$

Tujuan pendidikan islam sehrusnya sejalan dengan tujuan misi islam yaitu mempertinggi nilai-nilai akhlak hingga mencapai tingkat akhlakul karimah. ${ }^{15}$

Dasar adalah merupakan sumber kekuatan dan keteguhan berdirinya sesuatu karena tanpa adanya dasar pasti akan runtuh. Demikian juga dalam pendidikan, bahwa fungsi dasar adalah untuk menjamin keteguhan dalam mencapai tujuan. Dasar pendidikan adalah pandangan hidup yang melandasi aktifitas pendidikan. ${ }^{16}$ Karena dasar menyangkut ideal dan fundamental maka diperlukan landasan hidup yang kokoh dan komprehensif serta tidak mudah berubah.

Karena pandang hidup seorang muslim berdasarkan pada Al-Qur'an dan Sunnah, maka yang menjadi dasar pendidikan islam adalah Al-Qur'an dan Sunnah tersebut. Dasar pendidikan islam adalah identik dengan dasar ajaran islam itu sendiri, keduanya dari sumber yang sama yaitu Al-Qur'an dan Hadis, kemudian dasar dikembangkan dalam pemahaman para ulama dalam bentuk Qiyas Syar'i, Ijma yang diakui, Ijtihad dan tafsir yang benar dalam bentuk hasil pemikiran yang menyeluruh dan terpadu tentang jagad raya dengan merujuk kepada kedua sumber asal.

Landasan itu sendiri terdiri dari Al-Qur'an dan Sunnah nabi Muhammad SAW yang dapat dikembangkan dengan ijtihad.

a. Al-Qur'an

Al-Qur'an ialah firman Tuhan berupa wahyu yang disampaikan oleh Jibril kepada Nabi Muhammad SAW di dalamnya terkandung ajaran pokok yang dapat dikembangkan kedalam seluruh aspek kehidupan melalui ijtihad yaitu hungan dengan maslah keimanan yang disebut akidah dan berhubungan dengan masalah amal syari'ah. ${ }^{17}$

b. As Sunnah

${ }_{14}$ Ahmad tafsir, Ilmu Pendidikan dalam Persepektif Islam, cet ketujuh, (Bandung : PT REMAJA rosda karya, 2007), h. 46.

15 Jalaludin dan Usman Said, Filsafat Pendidikan Islam, Konsep dan Perkembangan Pemikirannya, cet pertamat, (Jakarta : PT Raja Grafindo Persada, 1994). h. 38.

16 Abudin Nata, Op. Cit., h. 59.

17 Zakiah Daradjat, Ilmu Pendidikan Islam, cet keenam, (Jakarta : Bumi Aksara, 2006), h. 19.

RI'AYAH, Vol. 02, No. 01 Januari-Juni 2017 
Sunnah adalah jalan, baik terpuji maupun yang tercela, "Barang siapa membuat sunnah terpuji maka baginya pahala bagi sunnah itu dan bagi orang lain yang mengamalkan sampai hari kiamat dan barang siapa menciptakan sunnah yang buruk maka padanya dosa sunnah-sunnah mereka sebelum sejengkal demi sejengkal dan sehasta demi sehasta" ${ }^{18}$

c. Ijtihad

Ijtihad adalah istilah para fuqaha, yaitu pemikiran yang menggunakan seluruh ilmu yang dimiliki oleh para ilmuwan syari'at Islam untuk menetapkan/menentukan semua hukum syari'at Islam dalam hal-hal yang ternyata belum ditegaskan hukumnya Al-Qur'an dan Sunnah. ${ }^{19}$

Ijtihad dalam hal ini juga meliputi seluruh aspek kehidupan termasuk aspek pendidikan, tetapi tetap berpedoman pada Al-Qur'an dan Sunnah. Namun demikian, ijtihad harus mengikuti kaidah-kaidah yang diatur oleh mujtahid tidak bertentangan dengan Al-Qur'an dan Sunnah tersebut. Karena itu ijtihad dipandang sebagai salah satu sumber hukum yang sangat dibutuhkan sepanjang masa Rasul Allah wafat. Sasaran ijtihad adalah segala sesuatu yang diperlukan dalam kehidupan, yang senantiasa berkembang. Ijtihad bidang pendidikan sejalan dengan perkembangan zaman yang semakin maju, terasa semakin urgen dan mendesak, tidak saja dibidang materi atau isi, melainkan juga dibidang sistem dalam arti yang luas.

Penerapan pendidikan Islam harus diwujudkan dalam upaya untuk pengembangan potendi kepribadian manusia yang meliputi:

a. Pengembangan Iman, yang diaktualkan dalam takwaan kepada Allah SWT, menghasilkan kesucian.

b. Mengembangkan Cipta, untuk memenuhi kebutuhan hidup material dan kecerdasan, memecahkan maslah-masalah yang dihadapi, menghisilkan kebenaran.

c. Pengembangan Karsa, Untuk menciptakan sikap dan tingkah laku yang baik (etika, akhlah, moral), menghasilkan keindahan.

d. Pengembangan Karya, untuk menjadikan manusia terampil dan cakap teknologi yang berdaya guna, menghasilkan kegunaan.

e. Pengembangan Rasa, untuk berperasaan halus (apresiasi seni, persepsi seni, kreasi seni), menghasilkan keindahan.

18 Mustafa Al Siba'i, Alih Bahasa Nurkhalis Masjid, Sunnah dan Peranannya dalam Penetapan Hukum Islam, cet ketiga, (Jakarta: Pustaka Firdaus, 1995), h. 1.

19 Ibid, h. 21.

RI'AYAH, Vol. 02, No. 01 Januari-Juni 2017 


\section{Muatan Nilai Pendidikan Islam Dalam Aktivitas Pengajian Lapanan di Desa Kedungwinangun}

Dalam penelitian skripsi ini terdapat banyak sekali muatan nilai-nilai pendidikan khususnya pendidikan agama islam dan etika moral masyarakat. Sesuai dengan hasil penelitian yang dilaksanakan.

Muatan nilai-nilai pendidikan dalam pengajian lapanan di Desa Kedungwinangun tersebut antara lain meliputi: mempertebal keimanan, meningkatkan ketakwaan, kesungguhan bekerja dan beribadah, solidaritas sosial, pendidikan etika/moral sosial masyarakat dan muatan nilai gerakan pendidikan kerohanian. ${ }^{20}$

Penjelasan pesan pendidikan yang dapat diambil tersebut, akan dibahas satu persatu dibawah ini yaitu :

a. Memperkuat/mempertebal Keimanan

Aktifitas ini merupakan sebuah media untuk mendekatkan diri kepada Allah SWT dan media untuk menuntut ilmu agama, selain ibadah wajib juga lainnya seperti shalat, zakat, dan puasa. Aktifitas ini maupun riadoh mempunyai tujuan yang sama yaitu untuk bertaqorub Ilallah dengan kesungguhan tekad dan keikhlasan hati. Kaitan kadar kadar keimanan seseoran dalam aktifitas ini mampu menjawab sebagaian persoalan yang dihadapi manusia dalam menjalani kehidupan di dunia ini. Seringkali sebagian besar orang mengambil jalan pintas untuk mencapai tujuan hidup yang mapan tanpa mengindahkan kaidah-kaidah agama maupun tuntutan syari'at Islam.

Dalam hal ini mengurangi pemikiran instant dan pragmatis karena sebagaian ahli yang melakukan aktifitas pengajian lapan dengan sungguh-sungguh baik dalam berusaha/berikhtiar dan serta berserah diri atas segala ketentuan Allah sudah barang tentu merasa yakin dan tenang serta bersifat Qana'ah menerima bagi rizkinya) secara proposional serta selalu bersifat khusnudzon atas segala karunia Allah SWT. Dalam kitab Durorul Bahiyyah telah dijelaskan definisi iman yaitu: "iman adalah menyakini dan memahami dalam hati, mengucapkan dengan lisan/perkataan serta menjalankan dengan perbuatan".

Merujuk dari kaida tersebut di atas adalah seseorang yang beriman selalu menyakini dan percaya adanya kekuasaan/kehendak Allah di dalam hati serta menjalankan apa yang menjadikan kewajiban sebagian seorang mukmin (orang yang beriman). Seseorang yang beriman di dalam hatinya tertanam keyakinan untuk tidak akan berpaling dari agama Allah (Islam) meskipun diiming-imingi kenikmatan dunia yang menggiurkan karena kebahagian yang bersifat sementara.

20 Zakiah darajat, Ilmu Pendidikan Islam, cet keenam, (Jakarta : Bumi Aksara, 2006), h. 21-22.

RI'AYAH, Vol. 02, No. 01 Januari-Juni 2017 
b. Meningkatkan Ketakwaan

Pendidikan yang kedua dalam aktifitas pengajian lapan adalah untuk meningkatkan ketakwaan kepada Allah SWT. Definisi dari takwa sendiri baik secara bahasa maupun secara istilah mempunyai pengertian masing-masing. Takwa secara bahasa artinya takut, sedangkan secara istilah adalah selalu menjalankan perintah Allah (ibadah) dan menjauhi segala larangannya (Amar Ma'ruf Nahi Mungkar).

Manusia memang harus takut hanya kepada Allah SWT. Takut disini bukan berarti menjauhkan dari Allah melainkan lari kembali kejalan Allah serta kepribadian luhur sebagai hamba yang bertakwa. Manusia hanyalah makhluk kecil di hadapanya-Nya yang tidak mempunyai daya upaya tanpa pertolongan-Nya. Para jama'ah pengajian lapanan ini diharapkan mampu meningkatkan ketakwaan setelah mengikuti jama'ah ini serta berpedoman bahwa segala rizki dan kenikmatan yang diperoleh merupakan Allah.

Usaha apapun dalam memperoleh karunia tersebut merupakan hanya sebagaian lantaran sehingga tidak mempunyai pemikiran bahwa apa yangtelah dimiliki merupakan hasil kerja keras dan jerih payahnya dengan menyampingkan bahwa hal tersebut merupakan pemberian dari Allah semata. Sifat ini harus dihindari manusia terlebih bagi orang yang telah masuk dalam jama'ah pengajian lapanan. Karena hal tersebut tersebut rentan sekali mendekati dengan kekufuran serta lupa dimana nasib mereka sebelumnya.

Sebagaian orang yang mengalami kesulitan hidup baik dari segi ekonomi, pendidikan, kesehatan serta usaha yang dihadapi akan selalu beribadah dengan tekun. Namun setelah kesejahteraan hidup mereka diperoleh maka akan sedikit terkikis aeaktifan dalam beribadah karena sangat sibuk dengan urusan di dunianya. Sikap ini sangat tidak diharapakan terlebih bagi jama'ah pengajian lapanan. Semakin tinggi kesejahteraan hidup yang diperoleh semakin tinggi pula efektifitas ibadah yang dijalankan baik ibadah mahdoh maupun ghoiru maghdoh.

c. Kesungguhan Dalam Bekerja/Berusaha

Barawal dari penjelasan diatas dapat ditelaah bahwa aktivitas pengajian lapanan merupakan awal dari proses seorang yang tadinya hanya tidak menjalankan suatu hal dengan tujuan tertentu. Sesuatu hal dalam pembahasan ini yaitu bekerja/ikhtiar.

Nilai-nilai pendidikan dalam aktifitas pengajian lapanan ini dimaksud agar manusia berusaha memenuhi hajat hidup yang beraneka ragam. Allah tidak akan menurunkan uang dari langit atau hujan emas yang dengan mudah dapat dinikmati oleh manusia. 
Allah tidak akan merubah nasib manusia apabila dirinya sendiri tidak berubah dengan kesungguhan dalam mencari sumber kehidupan. Perilaku hedonis maupun materialis haruslah dihindari dari diri setiap orang karena hanya akan menyiksa batin saja bilamana tidak dapat terpenuhi. ${ }^{21}$

Manusia manapun membutuhkan harta untuk memenuhi kebutuhan kehidupnya sehingga mereka berupaya untuk mendapatkannya dengan berbagai cara. Semestinya cara yang dipakai tentu harus halal sesuai ketentuan kaidah ajaran Islam yang berlaku. Hal yang harus diingat adalah semua harta yang kita miliki bukanlah milik kita sepenuhnya. Harta yang kita miliki adalah amanah/titipan Allah yang sewaktuwaktu akan diambil. Kesadaran seperti inilah yang diharapkan kepada setiap orang.

Hal ini mempunyai arti dan tujuan untuk menghindari resiko stres apabila seorang mendapat musibah yang menyebab hilangnya harta benda yang dimiliki. Sebagaimana kita lihat semakin banyak orang yang sibuk dengan urusan dunia yang telah lalai akan kewajiban sebagai hamba Allah.

Akan tetapi apabila harta yang dimiliki telah hilang/berkurang mereka akan baru menyadari akan kekeliruan yang telah dilakukan sehingga mereka mulai mendekatkan diri kepada Allah dengan harapan diberi karunia kembali. Hal semacam ini bukanlah yang diharapakan melainkan dalam keadaan apapun baik susah maupun senang kita tetap istiqomah menjalankan tuntunan syari'at Islam dan melaksanakan ibadah secara Kaffah (menyeluruh).

d. Kesungguhan Dalam Ibadah

Sesuai dengan penjelasan sebelumnya bahwa manusia diciptakan hanya untuk beribadah kepada Allah SWT. Hal itu sesuai dengan firman Allah dalam Al-Qur'an Q.S Adz Dzaariyaat Ayat 56.

Arab hal 51

$$
\text { لَيَعْبُدُونِ إِلَّا وَالْإِنْسَ الْجِنَ خَلَقَتُ وَمَا }
$$

Artinya:

"Dan aku tidak menciptakan jin dan manusia kecuali untuk menyembah kepada-Ku".22

Dalam hal ini mengajarkan tentang arti pentingnya pelaksanaan dalam beribadah harus dilaksanakan dengan sesungguh-sungguhnya.

21 Wawancara dengan marsiah Jama'ah Pengajian Lapanan Desa Kedungwinangun pada tanggal 10 januari 2017.

22 Abdullah bin Abdul Aziz Ali Sa'ud, Op.Cit., h. 862.

RI'AYAH, Vol. 02, No. 01 Januari-Juni 2017 
Di zaman modern yang serba canggih ini sperti sekarng banyak orang yang berpendapat bahwa orang melaksanakan ibadah dengan sungguh-sungguh tetapi masih banyak yang hidup dalam garis kemiskinan tetapi orang yang meninggalkan ibadah/abdah semaunya sendiri melainkan mereka yang berkehidupan yang layak. Hal ini menyebabkan pemikiran pemikiran kolot yang menyebabkan menurunnya efektivitas ibadah yang dilaksanakan. Penyakit yang semacam ini merupakan tantangan bagi umat Islam.

Tantangan berat seperti inilah yang dihadapi karena sebagaian besar jama'ah berangkat dari latar belakang yang bermacam-macam yang minimum pemahaman agamanya. Namun hal tersebut bukanlah sebagai hambatan melainkan cambuk dan bahan untuk intropeksi diri dalam menjalani kehidupan yang dilalui khususnya dalam berkehidupan ibadh.

Para jama'ah pengajian lapanan dituntun untuk mampu saling berinteraksi dengan yang lain tujuannya untuk salling mengisi dan melengkapi kekurangan masing-masing. Hal tersebut juga bertujuan untuk mempererattali persaudaraan antar jama'ah.

e. Meningkatkan Solidaritas Sosial

Manusia sesuai dengan kodratnya adalah makhluk sosial yang tidak dapat hidup sendiri tanpa bantuan orang lain. Manusia mempunyai keahlian, kelebihan dan kekurangan yang dimiliki. Sebagai penunjang kelancaran dalam berbagai aktifitas kehidupan yang dilaksanakan manusia bahkan harus salling berinteraksi untuk mendapatkan kemudahan dalam kegiatan yang dilakukan.

Melalui media interaksi dan musyawarah dapat menghasilkan sebuah kesepakatan yang disetujui bersama untuk dijalankan dengan penuh tanggung jawab. Kemajemukkan hajat hidup manusia terdiri dari dua macam yaitu hajat atau kepentingan dan kepentingan pribadi/sendiri. ${ }^{23}$

Kebutuhan hidup ini tentu dapat terpenuhi karena adanya interaksi dan kerja sama yang baik. Tanpa kerja sama yang baik niscaya tidak akan mendapatkan apa yang diharapakan selama ini. Nasib dan hidup seseorang tidaklah sama sebagaimana falsafah hidup layaknya roda yang berputar kadang diatas kadang dibawah. Baik orang yang bernasib mujur ataupun tidak semuanya adalah ketentuan Allah yang apabila dikaji secara mendalam merupakan ujian. Seseorang yang hidupnya dalam kesenangan (duniawi) merupakan ujian apakah dia membelanjakan nhartanya secara benar atau tidak sesuai dengan ajaran

${ }^{23}$ Zul Kifli dkk, Pola Interaksi Sosial, cet pertama, (Jakarta : Karya Media, 2004), h. 32.

RI'AYAH, Vol. 02, No. 01 Januari-Juni 2017 
agama seperti infak, amal jariyah, zakat, maupun sadaqah atau hanya menhambur-hamburkan hartanya dijalan yang tidak diridhoi oleh Allah seperti judi, mabuk-mabuk, narkoba, atau bermain perempuan.

Sebab dalam harta yang dimiliki ada hak bagi orang yang tidak mampu seperti fakir miskin, yatim piatu, orang jompo bahkan gelandangan dan anak jalanan yang tersebar di kota-kota besar yang hidup berada di kolong jembatan. Melalui uluran tangan bagi mereka mampulah memberikan kehidupan yang lebih baik ataupun memberi sedikit kebahagian untuk mereka, jama'ah pengajian lapanandalam hal ini tentang solidaritas sangat dianjurkan dan selalu diberikan dalam setiap kegiatan pengajian lapanan.

Mereka selalu berusaha ikhlas tentang harta yang mereka belanjakan untuk kepentingan bersama. Dalam hal ini para jama'ah pengajian lapanan pada umunya selalu berupaya menanamkan dan menerapkan rasa kesetiakawanan sosial dalam diri mereka baik dalam pelaksanaan maupun dalam kehidupan sehari-hari. ${ }^{24}$ Peningkatan Moral/Etika Masyarakat Berbicara masalah moral merupakan hal yang sangat melekat dalam kehidupan manusia. Moral merupakan cerminan dari karakter kepribadian seseorang, melalui moral yang dimiliki seorang dapat mengetahui kepribadian orang lain dan sebaliknya, moral banyak sekali sumbernya diantaranya Al-Qur'an dan Hadist, norma kesusilaan, norma adat, norma sosial, norma agama, dan norma hukum.

Bagaimana norma diatas dalam jama'ah pengajian lapanan berusaha diterapkan dalam kehidupan sehari-hari. Norma kesusilaan bersumber pada kaidah/aturan yang berlaku dalam suatu masyarakat tertentu yang merupakan norma-norma atau aturan-aturan yang telah disepakati bersama, sangsi dari norma ini mungkin saja dimarginalkan dalam masyarakat.

Norma adat bersumber dari adat istiada/kebiasan yang berlaku dalam masyarakat tertentuyang merupakan warisan dari leluhur secara turun temurun, pelanggran sangsi norma adat dapat berupa tidak diakuinya status keturunan dalam marga/golongan tertentu atau dapat pula pengucilan dari adat istiadat.

Norma agama bersumber dari aturan-aturan atau ajaran agama yang mengikuti bagi setiap pemeluknya. Sangsi pelanggaran ini selain menanggung dosa juga dapat cemoohan dari masyarakat sulit diterima

24 Wawancara dengan Hj. Munginah Jama'ah Pengajian Lapanan Desa Kedungwinangun pada tanggal 10 Januari 2017.

RI'AYAH, Vol. 02, No. 01 Januari-Juni 2017 
dalam kegiatan keagamaan. Norma hukum bersumber dari undangundang, sangsi norma ini dipertanggung jawabkan dihadapan hukum. ${ }^{25}$

Penjelasan dari norma-norma diatas menjadi pedoman agar lebih hati-hati dan selalu intropeksi dari dalam menjalani kehidupan baik secara individu maupun banyak 9masyarakat) yang merupakan sebuah tuntutan maupun kewajiban setiap orang. Harapan dalam pelaksanaan jama'ah pengajian lapanan mengenai pesan moral/etika masyarakat adalah bagaimana para jama'ah pengajian lapanan dapat lebih mawasdiri dalam melangkah dalam segala hal baik urusan dunia maupun urusan akhirat. Jama'ah pengajian lapanan selalu berusaha untuk menjadi mediator bagi seseorang yang mempunyai persoalan karena mungkin saja pernah dialami sesama jama'ah pengajian lapanan.

f. Pengajin Lapanan Sebagai Nilai Gerakan Pendidikan Kerohanian

Gerakan kerohanian merupakan kepercayaan kepada sang pecipta serta budaya spiritual yang berunsurkan tuntunan luhur dan wujud perilaku, hukum, ilmu suci yang dihayati dengan hati nurani dalam kesadaran dan keyakinan, dengan membina keteguhan tekad dan perilaku budi pekerti dalam tata pergaulan menuju kedewasaan rohani demi mencapai kesajehteraan hidup dunia dan akhirat.

Dengan melakukan kegiatan tersebut orang dapat membebaskan dirinya dari keadaan sekitarnya, hal ini dapat memberikan pikiran dan membuatnya mengerti dan menghayati hakikat hidup serta selaras antara kehidupan jasmani dan kehidupan rohani.

Apabila seseorang telah bebas dari beban kehidupan duniawi maka setelah orang tersebut melalui beberapa tahapan berikutnya, pada suatu saat akan dapat menemukan ketenangan batin dan ketentraman jiwa.

\section{Kesimpulan}

Pengajian lapanan bersifat rutin addalah pengajian yang di lakukan tiga bulan seklai ( selapan dina) pengajian yang dilakukan tiga bulan seklai hasil dari sepakatan bersama dalam pelasanaanya sebelum pengajian rutin di mulai dengan berpa rangkean kegitan di antarnya Rebana, sholawat, tahlil, dan pengajian inti.

Dalam nilai-nilai pendidikan islam dalam aktivitas jam'ah pengajian lapanan anatar lain adalah keimanan, ketaatan, beribadah/ketaqwaan, solidaritas sosial, kesuguhan dalam berkerja, etika sosial dengan keanekaragaman budaya dan gerakan pendidikan kerohanian dan stratifikasi

25 Wawancara dengan Kyai Saifudin Djufri Ketua Lapanan Desa Kedungwinangun pada tanggal 13 januari 2017.

RI'AYAH, Vol. 02, No. 01 Januari-Juni 2017 
sosila dalam masyarakat sebagai landasan kehidupan beragama menuju terbentuknya masyarakat aman, temtram, adil dan makmur.

\section{Referensi}

Abdullah bin Abdul Aziz Ali Sa'ud. Al Qur'an dan Terjemahannya. Jakarta : Yayasan Penyelenggara Penerjemahan / Penafsiran Al Qur'an. 1971.

Abudin Nata. Filsafat Pendidikan Islam, cet pertama. Jakarta : Gaya Media Pratama. 2005.

Ahmad Tafsir. Ilmu Pendidikan dalam Presepktif Islam, cet ketujuh. Bandung : PT REMAJA ROSDA KARYA. 2007.

Djamaludin Anclok dan Fuad Nashori Suroso. Psikologi Islam, cet pertama. Yogyakarta: Pustaka Pelajar. 1994.

H.A.R Tilaar. Perubahan Sosial dan Pendidikan Pengantar Pedagogik Transformatif Untuk Indonesia. Jakarta : PT Grasindo. 2002.

Jalaludin dan Usman Said. Filsafat Pndidikan Islam, Konsep dan Perkembangan Pemikirannya, cet pertama. Jakarta : PT Raja Grafindo Persada. 1994.

Mahfud Salahudin dkk. Metdologi Pendidikan Agama. Surabaya : Bina Ilmu. 1987.

Moh Irkhamni. "Nilai-Nilai Pendidikan dalam Aswaja menuju Inklusifisme Masyarakat NU". Skripsi STAINU Kebumen. 2006.

Mustafa Al Siba'i. Sunnah dan Peranannya dalam Penetapan Hukum Islam, Alih Bahasa Nurkholis Madjid, cet ketiga. Jakarta : Pustaka Firdaus. 1995.

Santoso Sembiring. Himpunan Perundang Undangan Republik Indonesia, cet pertama. Bandung : CV Nuansa Aulia. 2006.

Tim Prima Pena. Kamus Ilmiah Populer edisi lengkap referensi nIlmiah, Idiologi, Politik, Ekonomi, Sosial, Budaya dan Sain, cet pertama. Surabaya : Gita Media Perss. 2006.

Tutty Alawiyah. Strategi Dakwah di Lingkungan Majelis Taklim. Bandung: Mizan. 1997.

Wawancara dengan Kyai Saifudin Djufri Ketua Lapanan Desa Kedungwinangun pada tanggal 13 Januari 2017

Zakiah darajat. Ilmu Pendidikan Islam, cet keenam. Jakarta : Bumi Aksara. 2006.

Zul Kifli dkk. Pola Interaksi Sosial, cet pertama. Jakarta : Karya Media. 2004. 